Vol. 16, n² | 2012

Varia

\title{
Aurélien Lignereux, La France rébellionnaire : Les résistances à la gendarmerie (1800-1859)
}

Rennes, Presses Universitaires de Rennes, 2008, 365 p., ISBN

078-2-7555-0580-5.

\section{Clive Emsley}

\section{(2) OpenEdition}

\section{Journals}

Electronic version

URL: http://journals.openedition.org/chs/1383

DOI: $10.4000 /$ chs. 1383

ISSN: 1663-4837

\section{Publisher}

Librairie Droz

\section{Printed version}

Date of publication: 1 December 2012

Number of pages: 126-127

ISBN: 978-2-600-01642-1

ISSN: 1422-0857

\section{Electronic reference}

Clive Emsley, « Aurélien Lignereux, La France rébellionnaire : Les résistances à la gendarmerie

(1800-1859) ", Crime, Histoire \& Sociétés / Crime, History \& Societies [Online], Vol. 16, n² | 2012, Online since 13 March 2013, connection on 22 September 2020. URL : http://journals.openedition.org/chs/ 1383 ; DOI : https://doi.org/10.4000/chs.1383

This text was automatically generated on 22 September 2020

(C) Droz 


\section{Aurélien Lignereux, La France rébellionnaire : Les résistances à la gendarmerie (1800-1859)}

Rennes, Presses Universitaires de Rennes, 2008, 365 p., ISBN

078-2-7555-0580-5.

Clive Emsley

\section{REFERENCES}

Aurélien Lignereux, La France rébellionnaire : Les resistances à la gendarmerie (1800-1859), Rennes, Presses Universitaires de Rennes, 2008, 365 p., ISBN 078-2-7555-0580-5.

1 Twenty or so years ago few serious academic historians would have considered studying the French police or gendarmerie. In most social history the police and gendarmes made an entrance largely in the role of repressors of the plebeian and peasant classes. What a difference two decades makes! Work in this area in France is now second to none; much of the research into the gendarmerie is the result of the group clustered around Jean-Noël Luc at the Sorbonne, backed by General Georges Philippot and the Gendarmerie nationale itself. Would senior police officers in the United Kingdom take such an interest in preserving their heritage and fostering serious historical research?

2 Aurélien Lignereux is one of the young researchers who began under Luc's supervision. A few years ago he published a useful study of the initial guerre des polices when Joseph Fouché, as Minister of Police, regularly confronted Marshal Moncey, the Inspector General of the Gendarmerie. In La France rébellionnaire he follows this up with an account of the scrappy, but often lethal little confrontations between ordinary gendarmes and peasants in provincial France from the Consulate until mid-way through the Second Empire. In some ways this revisits the traditional area of peasant disorder prompting clashes with the force of order, but it is more nuanced than the older works 
emphasising, in particular, the role of the gendarmes as actors and not simply unthinking instruments of authority. As a result it presents interesting and thoughtprovoking conclusions.

3 Lignereux has mined a wide range of national and regional archives to reveal just under 4000 acts of violent disorder directed against gendarmes in the sixty-year period of his study. As might be expected, the violence against the gendarmes tended to peak during the First Empire, particularly over conscription demands, and thereafter in the periods of revolution of 1830 and 1848 and their immediate turbulent aftermaths. Generally speaking, however, across the whole period and omitting these significant and often extended peaks, the overall pattern of the résistances appears to have been one of decline; by 1859, fewer people on both sides were being killed in these confrontations and, in what might be called ordinary years, the number of confrontations also gradually declined. Lignereux discusses these changes in the context of the increasing physical presence of the gendarmerie on the ground from the upheavals of the Revolution, the state's increasing assertion of the legitimacy of violence, and the gradual decisions within rural communes to yield their power of enforcing local norms and to leave this authority, sometimes grudgingly, to the small brigades of gendarmes.

4 The book is structured chronologically in four parts. The first covers the period from the Consulate to the turbulence of the second restoration; the second runs to the stabilisation of the country following the Revolution of 1830 ; the third concludes at roughly the mid-point of Napoleon III's reign. The final part explores the period as a whole from the perspective of different regions and from the perspective of different levels of authority. There are informative maps and tables to illustrate the cantonal and departmental distribution of various forms of disorder at various times, as well as the scale and the varieties of violence deployed by both sides in a confrontation. The centres of trouble correspond, as might be expected, with old revolutionary divisions as well as with the broader contrasts highlighted many years ago by André Siegfried and probed subsequently and significantly by Eugene Weber. As a whole the book is impressively researched, cogently and persuasively argued. If there is a slight niggle it is that the chronological thrust leaves the reader with an impression of legitimacy achieved, or rather well on the way to being achieved, by the second half of the nineteenth century. The legitimacy of police officers, and by extension, of gendarmes is perhaps better understood as an issue that is constantly contested - though perhaps not always by violence. Lignereux's study needs now to be followed up with an exploration of the gendarme's legitimacy during the Third Republic, particularly during the years of the anti-clerical campaign. Equally interesting would be an analysis of this legitimacy during the inter-war period and after the embarrassments and difficulties imposed on the gendarmes during the First World War. 


\section{AUTHORS}

CLIVE EMSLEY

Open University

c.emsley@open.ac.uk 